\title{
COMPARISON OF DATA-DRIVEN LANDSLIDE SUSCEPTIBILITY ASSESSMENT USING WEIGHT OF EVIDENCE, INFORMATION VALUE, FREQUENCY RATIO AND CERTAINTY FACTOR METHODS
}

\author{
Salman FAROOQ * and Mian Sohail AKRAM \\ Institute of Geology University of the Punjab, Lahore, Pakistan+ \\ *Corresponding author's e-mail: salman.geo@pu.edu.pk
}

\begin{tabular}{l} 
ARTICLE INFO \\
\hline Article history: \\
Received 9 April 2021 \\
Accepted 25 May 2021 \\
Available online 6 June 2021 \\
\hline
\end{tabular}

Keywords:

Landslide susceptibility

Weight of evidence

Information value method

Frequency ratio

Certainty factor

Geographic information system
ABSTRACT

Landslide susceptibility assessment is essential for development activities and disaster management in the mountainous regions to identify the landslide-prone areas. The present study aimed to evaluate and compare the efficacy of data driven quantitative models of landslide susceptibility assessment using geospatial tools in Jhelum valley of the Himalayas. This area suffers from extreme rainfall events due to the local climate and has experienced significant and widespread landslide events in recent years. Four probabilistic data-driven models are employed for this purpose, which includes the weight of evidence (WOE), information value method (IVM), frequency ratio (FR), and certainty factor (CF). These assessed models are based on integrating landslide contributing factors and a ground truthing-based landslide inventory of 437 landslides. The landslide susceptibility maps were presented by categorizing the study area into very low to very high susceptibility zone by Jenks natural breaks method. The performance of models was evaluated by a sensitivity analysis using Receiver Operator Curve (ROC) method. The ROCvalidated results of success rate curves for WOE, IVM, FR and CF were $80 \%, 78 \%, 77 \%$, and $76 \%$ respectively. The prediction rate curve of WOE, IVM, FR, and CF was $78 \%, 77 \%, 75 \%$, and $78 \%$ respectively. The results showed the reasonable efficiency of applied models for landslide susceptibility assessment in the study area and applicable to regions with similar geomorphological conditions. Conclusively, the comparison of applied models revealed the promising results of used approaches.

\section{INTRODUCTION}

Landslides are a significant global geological hazard that causes a great number of human casualties and substantial harm to infrastructures, natural resources, and ecosystems. Therefore, the potential vulnerability to landslide hazards in mountainous and hilly terrain areas needs to be considered and evaluated adequately. To reduce the catastrophic damages associated with the landslide hazards, the understanding of triggering mechanism, mode of movements, soil and rock mechanical properties and engineering behavior is necessary (Guzzetti et al., 2012; Aditian et al., 2018). Based on the survey on economic losses, poverty, and disaster conducted by the Centre for Research on Epidemiology of Disasters (CRED) from 1998-2017 (Pascaline and Rowena, 2018), landslides affected about 4.8 million people and reported death tolls were about 18,000 worldwide. Economic losses due to landslides are estimated $\$ 4$ billion annually worldwide (Pascaline and Rowena, 2018). The annual percentage of casualties and economic losses are expected to increase globally with unplanned urbanization in the mountains.

Landslide events are controlled by both environmental and triggering factors (Corominas et al., 2014). The environmental factors are related to geological settings (e.g., types of rock, faults, and structure), elevation (e.g., drainage density, relief, curvature, aspect, and slope angle), hydrology (e.g., soil moisture and proximity to drainage), and land use conditions (e.g., vegetation, buildings and roads). The triggering factors are those which can initiate the movements in slopes (e.g., precipitation and earthquakes). For landslide hazard and susceptibility studies, it is generally assumed that the combination of these environmental factors and triggering factors are responsible for the occurrence of landslides and need to be evaluated to mitigate the damage caused by landslides.

In the past few decades, several approaches have been proposed for landslide susceptibility assessment on the assumption that potential landslides can be predicted by evaluating the relationship between the past landslides and their contributing factors (Guzzetti, 2002; Zhao and Chen, 2020). Although both quantitative and qualitative methods can be used to carry out landslide susceptibility mapping, the general steps are similar, such as; i) preparation of landslide inventory map, ii) identification and data preparation of landslide causative factors, iii) evaluation of 
causative factors by integrating with quantitative or qualitative techniques, and iv) and classification of the investigated area into different susceptibility zones (Devkota et al., 2013; Chen et al., 2016). The qualitative approaches are the knowledge-driven methods based on the experience of an expert or a group of experts (Abella and Van-Westen, 2008). In such approaches, experts analyze the landslides, determine the key factors, and recognize the area with similar conditions based on landslide inventory. Some indirect qualitative mapping techniques include rating and weighting (e.g., Fuzzy logic, Analytic Hierarchy Process, and multiclass overlay) (Yalcin, 2008; Kanungo et al., 2011; Yalcin et al., 2011). The limitations of these approaches are the participation of subjective judgments and the limitation of the non-quantifying weight of each contributing factor. The outcomes of these methods rely entirely on the expert knowledge and are subjective-based (Guzzetti, 2002).

The quantitative approaches integrate statistical models to evaluate the probability of landslides into varying degrees of different susceptible zones (Carrara et al., 1995; Van-Westen, 2002; Reichenbach et al., 2005; Pasang et al., 2020). These data-driven methods use recent and past landslide information to obtain a reliable estimate of the landslide probability. The quantitative approaches include bivariate statistical methods (e.g., the weight of evidence, information value method, and frequency ratio), and multivariate statistical methods (logistic regression, artificial neural networks, discriminant analysis) (Regmi et al., 2010; $\mathrm{Xu}$ et al., 2012; Guri and Patel, 2015; Chen et al., 2016; Aditian et al., 2018; Chang et al., 2020). These approaches are less subjective than qualitative methods; however, they require good quality of landslide inventory database. Different methods have been suggested for generating landslide susceptibility mapping with the advancement in geospatial tools like remote sensing (RS) and geographic information systems (GIS). However, an agreement on which technique is the most effective has not yet been established.

The study area lies in the high mountain regions of the Himalayas, where landslides pose a significant threat to human life and infrastructure. This region is also strategically important where occasional landslides cause blockage of road networks. The main objective of this study is to investigate the significance of landslide causative factors and compare the efficacy of four different data-driven methods of quantitative landslide susceptibility assessment. This comparative study uses the models of the weight of evidence (WOE), information value method (IVM), frequency ratio (FR) and certainty factor $(\mathrm{CF})$ to produce the landslide susceptibility of the Jhelum Valley of the Himalayas. The present research applies an established technique to an area yet unstudied for quantitative methods based landslide susceptibility assessment.

\section{METHODOLOGY}

\subsection{OVERVIEW OF THE STUDY AREA}

The present work focuses on the Jhelum Valley, which is situated in the Himalayas of northern Pakistan. The Jhelum Valley covers an area of about $708 \mathrm{~km}^{2}$ (Fig. 1). The elevation ranges from 777 to $3992 \mathrm{~m}$, and geomorphology is dominated by the high-rise mountains with steep slopes. The river Jhelum follows a trend of the southeast to northwest, similar trend is followed by the valleys and ridges. The northeast and northwest parts of the region are relatively high in relief compared to other parts of the research area. The study area has a long history of disasters related to landslides, most of which are triggered by catastrophic natural hazards such as the October 2005 Kashmir earthquake, flood of 2010, and occasional intensive rainfalls. The massive landslide triggered in the study area was the Hattian rock avalanche, which affected approximately $1.8 \mathrm{~km}^{2}$ area (Harp and Crone, 2006) and produced a natural dam by blocking the river Jhelum tributaries. The reported deaths from the Hattian avalanche were about 575 (Dunning et al., 2007). Similarly, the flood of 2010 compelled about 149 families to evacuate their houses and caused several causalities (Hicks and Burton, 2010). The frequent incidents of landslides in the study area are causing loss of lives and damages to infrastructures and need immediate attention.

The geology of the area (Table 1) is complex due to the presence of major fault zones comprised of the sheared and highly fractured rock, making it more vulnerable to failures during seismic activity and intense rainfall episodes. Concentrated fissuring, spreading, and creeping have been observed in the surrounding, making the area more dangerous for slope failures (Shafique et al., 2016). The seismic events in the study area resulted in many great mass movements due to the presence of highly faulted, jointed, and fragile rocks (Harp and Crone, 2006; Dunning et al., 2007; Owen et al., 2008; Shafique et al., 2016). Most mass movements in the research area are clustered along the Main Boundary Thrust (MBT), Panjal Thrust (PT), and Muzaffarabad Fault (MF). MBT and PT run across the study area with almost northwest-southeast orientation (Schneider, 2009; Basharat et al., 2012). Mass movements in the hanging wall of MF are higher in quantity as compared to the footwall (Mahmood et al., 2015).

The rocks belonging to the deformation zones of MBT and PT are characterized by the contact of Precambrian (Salkhala slate/schist) and Triassic to Carboniferous (metasedimentary rocks). These rocks were strongly deformed, broken, and shredded during subsequent episodes of deformation (Bossart and Ottiger, 1989).

\subsection{LANDSLIDE INVENTORY}

The landslide inventory is a database of the spatial distribution and characteristics of past 


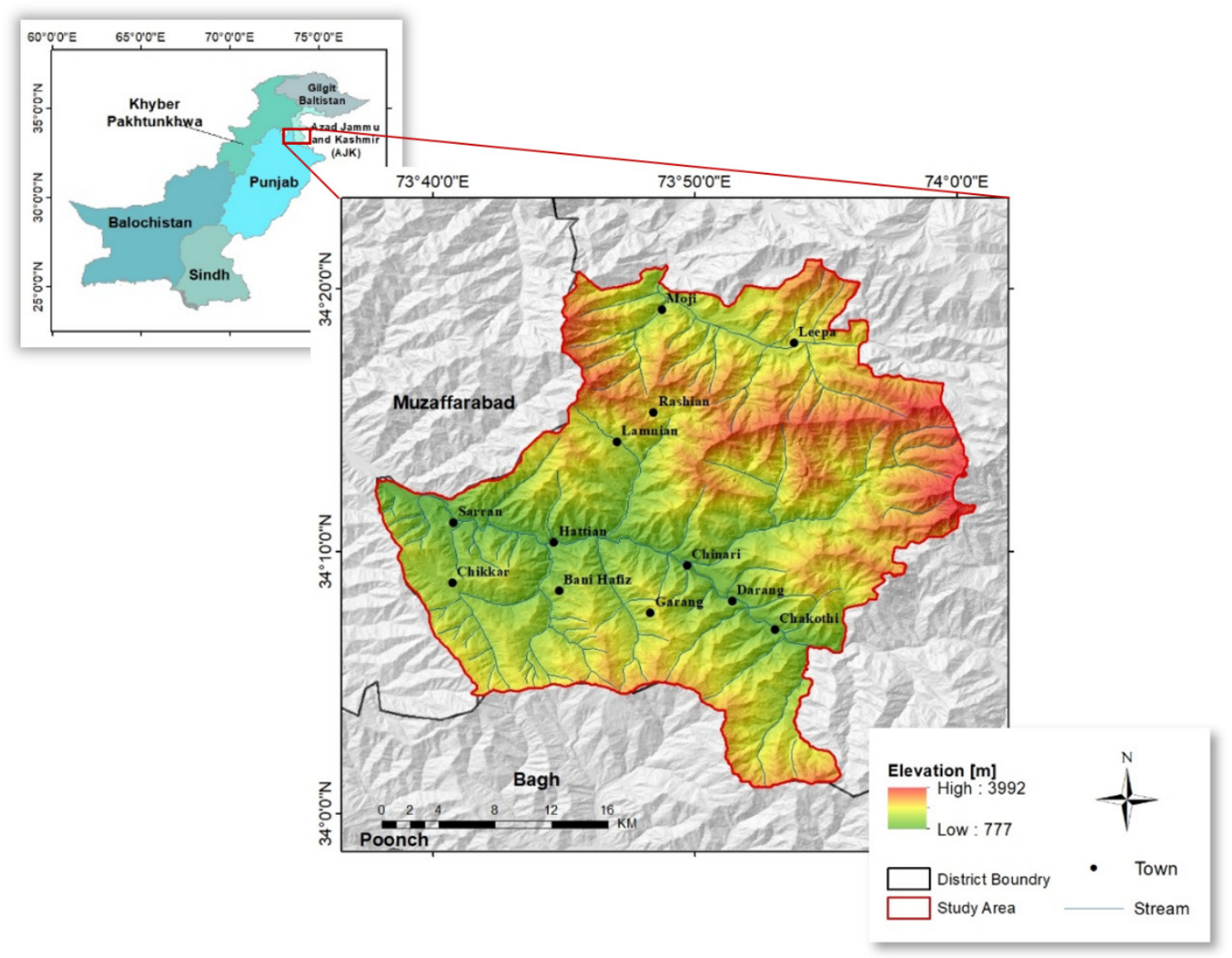

Fig. 1 Geographical location of the study area in the context of land, provinces, and districts.

Table 1 Geologic unit of the study area and descriptions (Geological Survey of Pakistan).

\begin{tabular}{llll}
\hline Group & Formation & \multicolumn{1}{c}{ Age } & \multicolumn{1}{c}{ Lithology } \\
\hline Group 1 & Quaternary & Holocene & $\begin{array}{l}\text { Stream channel, surficial, and terrace deposits (sand, silt, } \\
\text { clay, and gravels) }\end{array}$ \\
\hline Group 2 & Kamlial Formation & Late Miocene & Sandstone, mudstone, and conglomerate \\
\hline Group 3 & Murree Formation & Early Miocene & Sandstone, siltstone, shale, claystone and conglomerate \\
\hline Group 4 & $\begin{array}{l}\text { Panjal } \\
\text { Metasediments }\end{array}$ & $\begin{array}{l}\text { Triassic to } \\
\text { Carboniferous }\end{array}$ & Metacarbonate, quartzite and graphitic phyllite \\
\hline Group 5 & Panjal Volcanics & $\begin{array}{l}\text { Triassic to } \\
\text { Carboniferous }\end{array}$ & Basaltic lava flows with Tuffaceous layers \\
\hline Group 6 & Rashian Granite & Cambrian & $\begin{array}{l}\text { Feldspathic Epidote, Quartz, Muscovite, Biotite, } \\
\text { Tourmaline, Rutile }\end{array}$ \\
\hline Group 7 & Salkhala Formation & Late Precambrian & Graphitic schist, talc schist and quartz mica schist
\end{tabular}

landslides. It is considered fundamental and essential information for any landslide susceptibility mapping. The relationship between past landslides and their causative factors is established for modeling a successful landslide susceptibility mapping (Duman et al., 2005; Ghosh et al., 2012). Systemic landslide inventory requires consistent quality data from a spatial database in combination with ground-truthing field surveys.

In the present study, landslide susceptibility assessment was followed by developing an inventory of landslides to establish the spatial location of the past slope movements. A total of 437 landslides were recognized based on satellite imageries, literature records, and extensive field surveys for ground-truthing. The study area was about $708 \mathrm{~km}^{2}$, and the area occupied by the landslides was approximately $10,291,545 \mathrm{~m}^{2}$. The preparation of landslide inventory showed that most of the landslides were distributed along with the road networks and near the drainage. Rotational and translational slides, topples, falls, and flows were typical rock and soil movements observed during field visits (Fig. 2a). In the study area, earthquakes, intensive rainfall, erosion, and anthropogenic activities are significant triggering factors for slope instabilities. The division of 


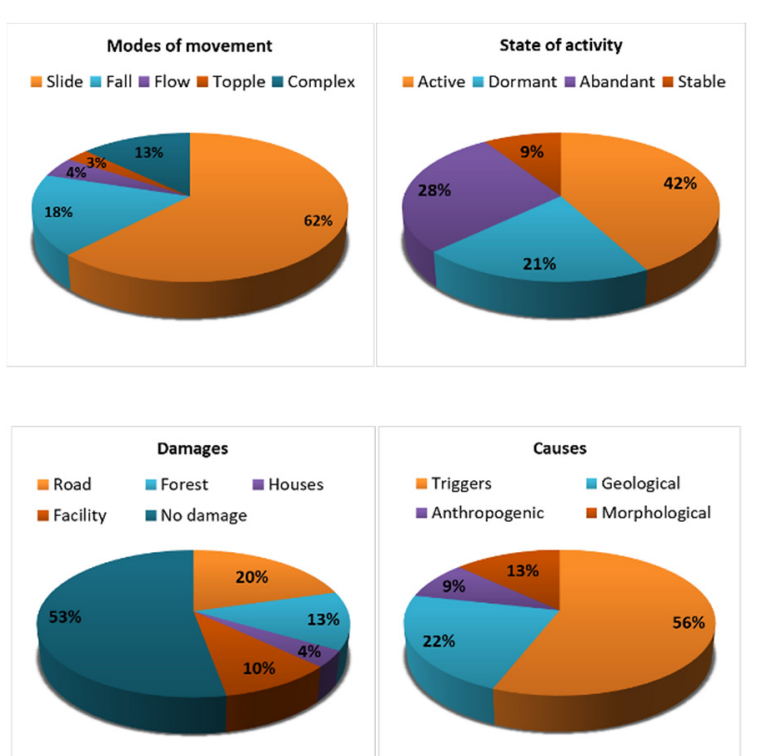

(a)

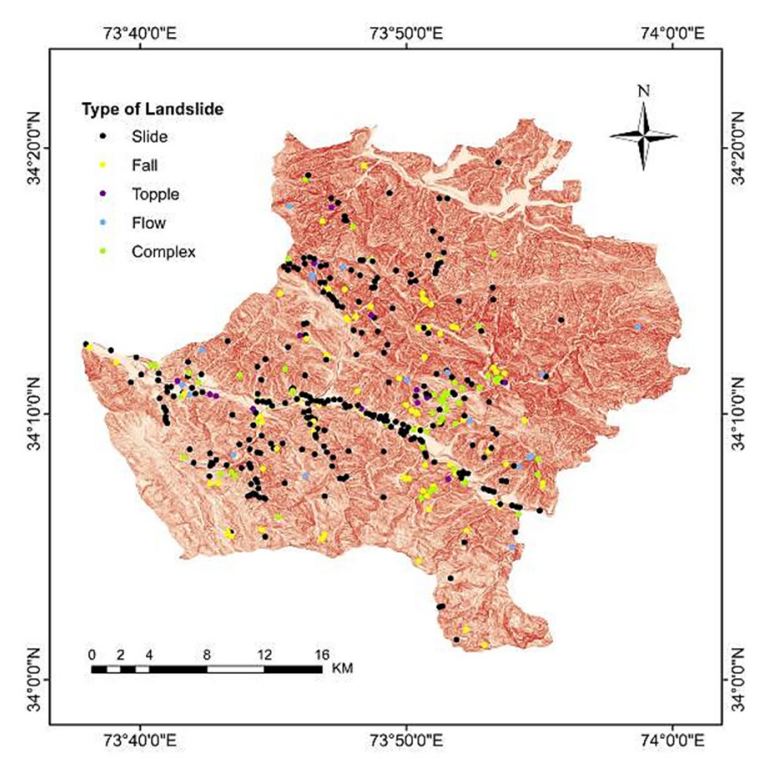

(b)

Fig. 2 Landslide inventory dataset (a) graphical representation of landslide inventory information (b) types of landslides in the study area.

recognized landslides was made into a training (70\%) and test $(30 \%)$ dataset. The training dataset is required for computation and integration of models, and the test dataset is for validation of the models.

In developing a landslide data inventory, field surveys, knowledge of historical literature, and local interviews helped. The information on modes of movements, state of activity, causes and damages were gathered, as shown in Figure 2a. The landslide kinematic mode of movements was recognized, and $61 \%$ of the total landslides were found to be slides (translational, rotational), $18 \%$ of the landslides were falls, $13 \%$ were flows, and 5\% were topples. During the field visits, it was observed that the number of active landslides (42\%) was greater and the number of landslides which were stabilized $(9 \%)$ were near a residential area and alongside the road network. The total landslides induced by the seasonal precipitation and earthquakes was $56 \%$.

\subsection{DATA PREPARATION OF CAUSATIVE FACTORS}

The landslide causative factors are known to be a significant influencing contributor for the occurrence of landslides. Each causative factor importance is analyzed based on the weight calculation in the statistical models (Yalcin et al., 2011; Chen et al., 2016; Iqbal et al., 2021). The contribution of causative factors is determined by preparing the factors map and superimposing it with the landslide inventory dataset. The causative factors considered for the present study were related to geology (lithology, distance to fault), anthropogenic activity (distance to road), and geomorphology (distance to drainage, slope angle, land cover, and NDVI).
The database of causative factors is prepared using the RS and GIS geospatial tools, and sources of data are presented in Table 2. The methodology adopted for the present study is shown in Figure 3.

\subsubsection{GEOLOGICAL FACTORS}

The lithology is a widely accepted crucial influencing factor for the landslide susceptibility zonation (Anbalagan, 1992; Meena et al., 2019; Dikshit et al., 2020). The different geological units demonstrate substantial differences in slope instability (Aditian et al., 2018). The dimensions and type of landslides are also characteristics of the lithology ( Du et al., 2017). Lithological information of the present study area is presented in Table 1. The geological map was produced utilizing the already published map by the Geological Survey of Pakistan and additional modifications were made through collecting data from the field survey. The thematic causative factor map of the lithology is prepared by identifying seven lithological formations in the study area (Fig. 4a).

Proximity to faults influences the mass movement by contributing to the surface structures and weakening of the rocks (Tibaldi et al., 1995; Bonham-Carter, 2014). Researchers have reported that decreasing distance to faults increases the likelihood of landslide occurrence (Du et al., 2017). Three major faults, the Main Boundary Thrust (MBT), Panjal Thrust (PT) and Muzaffarabad fault (MF) were present in the study area. Rocks near these fault zones are highly deformed, fractured, and sheared, becoming more vulnerable to mass instabilities. Each fault line buffer zone was established in ArcGIS into five classes; 0-1000 m, 1000-2000 m, 2000-3000 m, 3000$4000 \mathrm{~m}$, and distance greater than $4000 \mathrm{~m}$ (Fig. 4b). 
Table 2 Source of information and acquired data summary.

\begin{tabular}{llll}
\hline Causative factor & Data source & Resolution & Description \\
\hline Lithology & Geological map & $1: 50,000$ & Lithological units \\
Distance to fault & Geological map & $1: 50,000$ & Lithological units \\
Distance to road & Topographic map & $1: 50,000$ & Natural break \\
Slope angle & ASTER DEM & $12.5 \mathrm{~m}$ & Natural break \\
Distance to stream & ASTER DEM & $12.5 \mathrm{~m}$ & Natural break \\
NDVI & Sentinel 2 & $12.5 \mathrm{~m}$ & Natural break \\
Land cover & Sentinel 2 & $12.5 \mathrm{~m}$ & Supervised classification \\
Landslide Inventory & Field visits and Satellite imageries & $1: 50,000$ & Area polygons \\
\hline
\end{tabular}

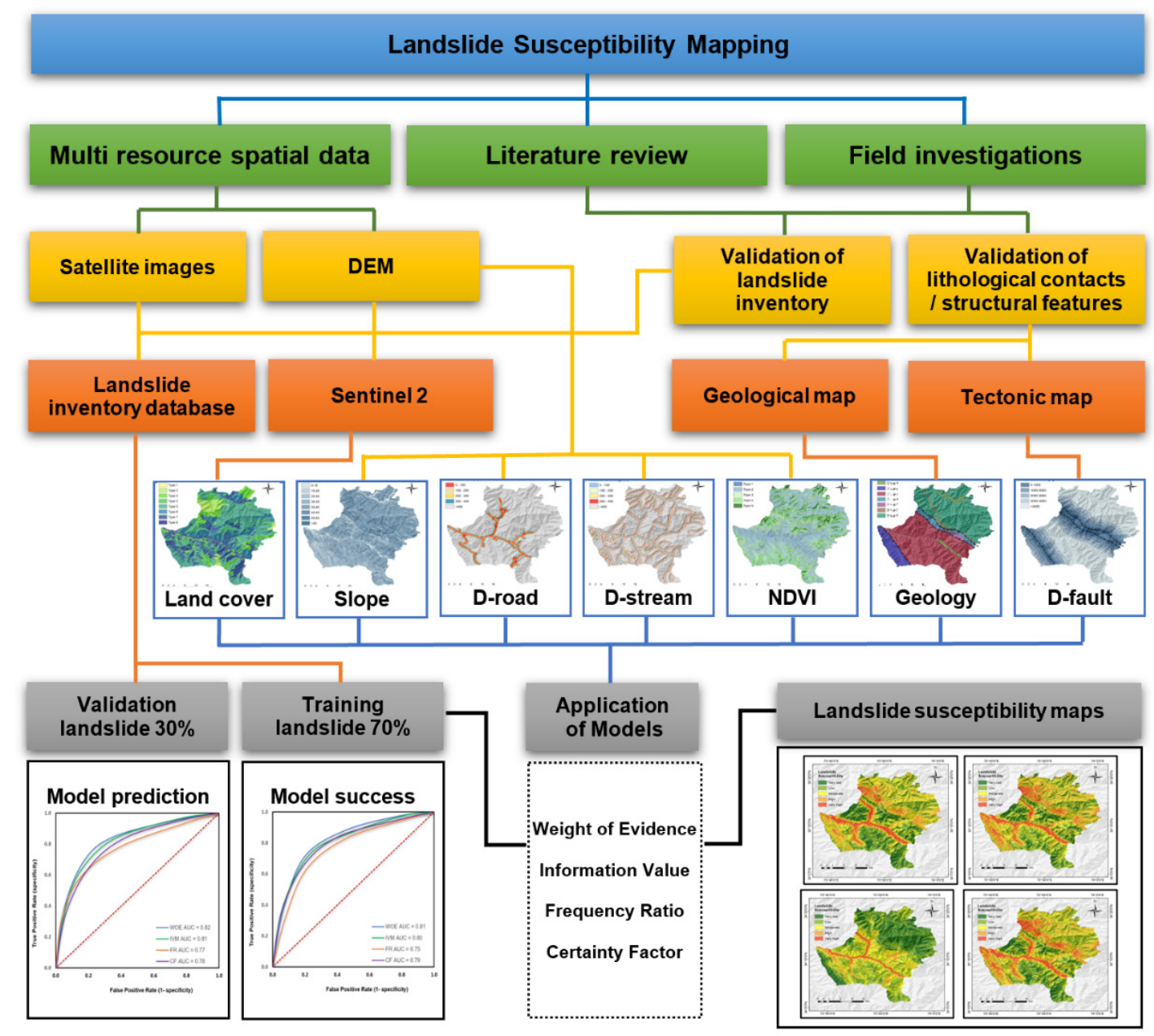

Fig. 3 Overview of the methodology adopted for the landslide susceptibility.

\subsubsection{ANTHROPOGENIC FACTORS}

Human activities have an adverse impact on the natural slopes, significantly those activities which required the modification of natural slopes by cutting and excavation. Proximity to road was considered an important anthropogenic factor. As shown in Figure $4 \mathrm{c}$, the causative factor distance to road was categorized into five classes; $0-100 \mathrm{~m}, 100-200 \mathrm{~m}$, 200-300 m, 300-400 m, and $>400 \mathrm{~m}$.

\subsubsection{GEOMORPHOLOGICAL FACTORS}

The slope angle is a significant topographical feature, which plays an important role in landslides occurrence. It influences the slope surface runoff, the weathering layer, and the stress distribution in the slope (Du et al., 2017; Meena et al., 2019). The gentler slopes have less probability of landslides over the steep slopes, possibly because of the associated shear stresses (Guo et al., 2015). In this research, the causative factor of slope angle was computed in the ArcGIS Spatial Analyst tool using $12.5 \mathrm{~m}$ resolution DEM data derived from ASTER. As shown in Figure 4e, the causative factor was divided into eight classes: $0-15,15-25,25-30,30-35,35-40,40-45$, $45-55,>55$ degree. 

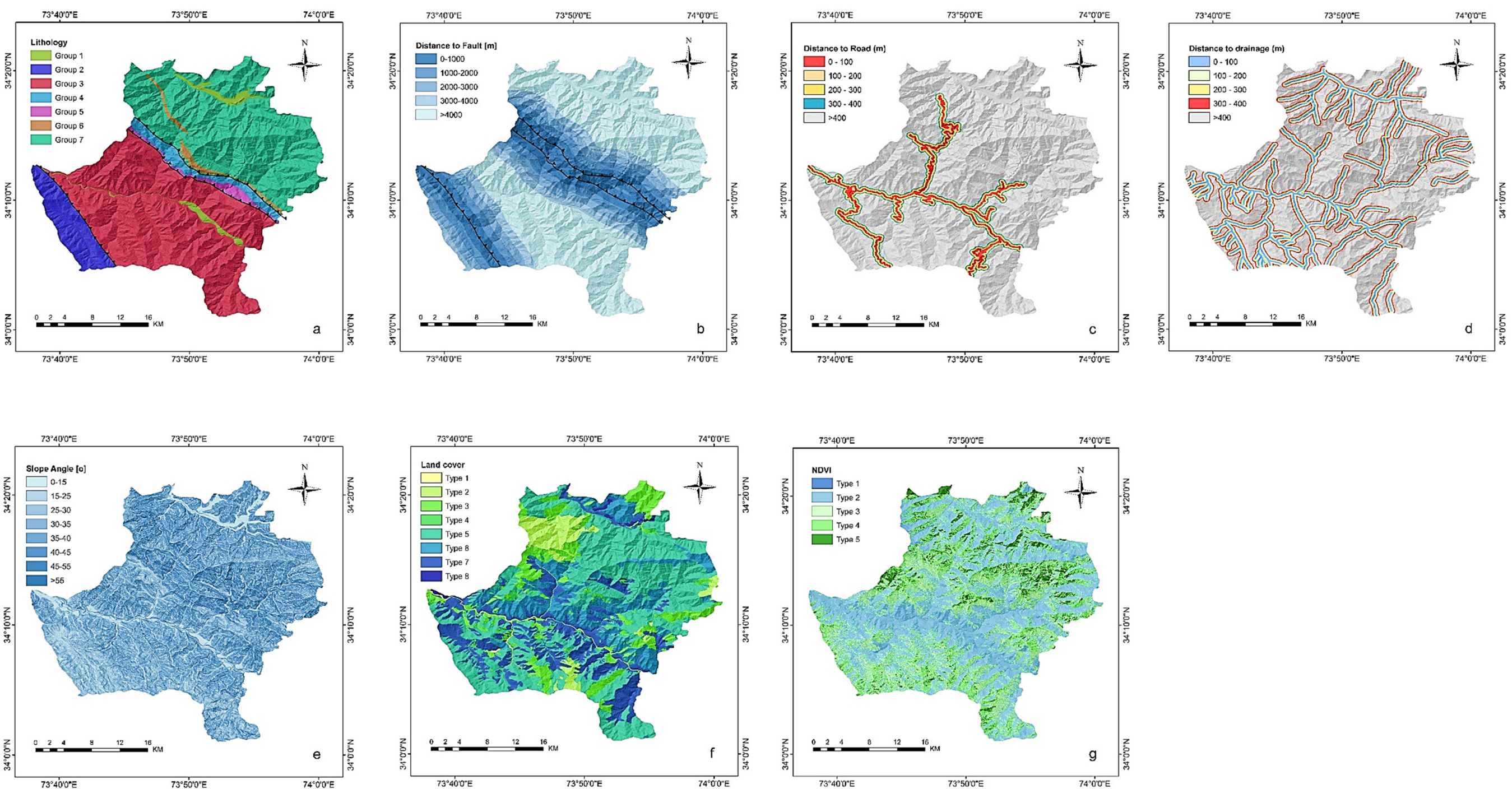

Fig. 4 Thematic parameter maps of causative factors used for the calculation of models weights (a) lithology, (b) distance to fault, (c) distance to road, (d) distance to drainage, (e) slope angle, (f) land cover, and (g) NDVI. 
Proximity to drainage is an important landslide causative factor, which may adversely affect by increasing the pore water pressure and slope toe erosion (Guo et al., 2015; Raja et al., 2017). The weak lithologies and soil cover in the study area are easily erodible by the water action. The causative factor proximity to drainage is considered observing a major landslide triggering factor in the region as proximity to water body has higher chances of landslide occurrence (Du et al., 2017). The research area is drained by the river Jhelum and its tributaries. All the tributaries and river Jhelum engaged in headward erosion and transportation of sediments. Using spatial analyst tools in ArcGIS, different buffer zones of the distance to streams were obtained with ASTER DEM. As shown in Figure 4d, the distance to drainage was classified into five buffer zones: 0-100 m, 100-200 m, 200-300 m, 300-400 m, and $>400 \mathrm{~m}$.

Land cover is a significant influencing factor that contributes to reduce soil erosion. During long-term and short-term rainfalls, a great accumulation of water is facilitated by infiltration caused by the plant roots and vegetation. Based on the study area conditions, the following eight classes were categorized (Fig. 4f): water bodies (type-1), snow (type-2), shrubland (type-3), settlement (type-4), forest (type-5), bare ground (type-6), agricultural land with scattered houses (type-7), and agricultural land (type-8).

The causative factor NDVI is a degree of vegetation density of the slope surface. The vegetation cover stabilizes the loose soil slopes, and its removal can expose the slope surface to different weathering processes, which can potentially lead to landslides (Shu et al., 2019). It is an important factor that has an impact on soil cohesion and shear resistance in slopes. The causative factor NDVI was divided into five classes on the base of vegetation density (Fig. 4g): no vegetation (type-1), meager vegetation (type-2), sparse vegetation (type-3), moderate vegetation (type-4), and dense vegetation (type-5). The following formula is used to determine the NDVI (Wittich and Hansing, 1995).

$N D V I=(I R-R) /(I R+R)$

Where $R$ is the red band of the electromagnetic spectrum, and $I R$ is the infrared band of the electromagnetic spectrum.

\subsection{APPLICATION OF DATA-DRIVEN METHODS}

\subsubsection{WEIGHT OF EVIDENCE}

The statistical based technique, weight of evidence (WOE) is widely accepted for producing a reliable landslide susceptibility zonation (Regmi et al., 2010; Guri and Patel, 2015; Nohani et al., 2019). Bonham-Carter (1989) initially developed this approach to be applied for potential mineral estimation and later modified by Van Westen (1993) for the landslide susceptibility assessment. This quantitative modeling technique measures the positive and negative (W+, W-) likelihood of landslide events. In this approach, each landslide causative factor is divided into predicate classes and the statistical relationship of each class is analyzed individually. The weights are calculated by the statistical formula and then overlaid to generate the susceptibility map.

The positive and negative weight index $(\mathrm{W}+, \mathrm{W}-)$ for factor class $\mathrm{Ni}$ is calculated using the following equation:

$W^{+}=\ln \left(\frac{P\{N i / S\}}{P\{N i / \bar{S}\}}\right)$

$W^{-}=\ln \left(\frac{P\{\overline{N l} / S\}}{P\{\overline{N l} / \bar{S}\}}\right)$

Where $P\{N i / S\}$ and $P\{N i / \bar{S}\}$ are the conditional probabilities for the presence of landslide causative factor $N i$, given that a landslide pixels $\mathrm{S}$ and non-landslide pixels $\bar{S} . P\{\overline{N \imath} / S\}$ and $P\{\overline{N \imath} / \bar{S}\}$ are the conditional probabilities for the absence of landslide causative factor $N i$.

The final weight $(W)$ is calculated for each causative factor of $\mathrm{n}$ disjunctive classes having the positive and negative weights for the presence and absence of landslide causative factor classes using the following equation.

$W=W_{i}^{+}+\left[\sum_{j=1}^{n} W_{j}^{-}\right]-W_{i}^{-}$

Where $W_{j}^{-}$is the absence of other classes, $W_{i}^{+}$is the presence of $\mathrm{i}$-th class, and $W_{i}^{-}$is the absence of the ith class.

The WOE modeling is based mainly on the indexes $W+$ and $W-$, which are further used to calculate the final weight $W$. These indexes represent the significance of the positive and negative spatial association of the factor class. As shown in Table 3, the final weights calculated using equation 4 show the spatial relationship between landslides and causative factors. The landslide susceptibility map (LSM) is obtained by assigning the calculated weights to each thematic layer and with the summation of all thematic causative factors maps, using the following equation.

$$
\begin{aligned}
& L S M_{W O E}=W O E_{\text {lithology }}+W O E_{\text {fault }}+ \\
& \quad+W O E_{\text {slope angle }}+W O E_{\text {distance to road }}+ \\
& \quad+W O E_{\text {distance to drainage }}+W O E_{\text {land cover }}+ \\
& \quad+W O E_{N D V I}
\end{aligned}
$$

\subsubsection{INFORMATION VALUE METHOD}

The information value method (IVM) is a datadriven technique that can evaluate the objective assessment for landslide susceptibility. This method calculates the relationship between the dependent variable (landslides) and the independent variable (causative factor) based on the weightage of the influence (Yin and Yan, 1988; Sarkar et al., 2012). The calculation of IVM weight is based on the rationing of each factor class landslide density to the total landslide density in the respective causative factor (Pradhan et al., 2012; Sarkar et al., 2013; Wang et al., 2014). The weight of each causative factor is computed by applying the following equation: 
Table 3 The spatial relationship between landslide causative factors and landslides by using WOE, IVM, FR and CF models.

\begin{tabular}{|c|c|c|c|c|c|c|c|}
\hline \multirow{2}{*}{$\begin{array}{c}\text { Causative } \\
\text { Factors }\end{array}$} & \multirow{2}{*}{ Factor Class } & \multicolumn{2}{|c|}{ Area $(\%)$} & \multicolumn{4}{|c|}{ Models weights } \\
\hline & & Class $\left(\mathrm{m}^{2}\right)$ & Landslide $\left(\mathrm{m}^{2}\right)$ & WOE & IVM & FR & $\mathrm{CF}$ \\
\hline \multirow{7}{*}{ 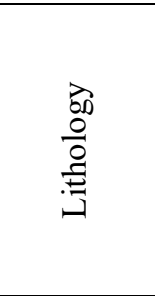 } & Group 1 & 16947188 & 309063 & 0.182 & 1.869 & 6.481 & 0.855 \\
\hline & Group 2 & 51139063 & 70781 & -2.495 & -0.236 & 0.790 & -0.212 \\
\hline & Group 3 & 316526563 & 5767344 & 0.869 & -2.094 & 0.123 & -0.878 \\
\hline & Group 4 & 23692500 & 365313 & 0.009 & 0.483 & 1.621 & 0.388 \\
\hline & Group 5 & 12684375 & 370313 & 0.679 & 0.316 & 1.372 & 0.274 \\
\hline & Group 6 & 11467344 & 53281 & -1.224 & 0.955 & 2.597 & 0.622 \\
\hline & Group 7 & 275803125 & 1024375 & -1.800 & -0.883 & 0.413 & -0.589 \\
\hline \multirow{5}{*}{ 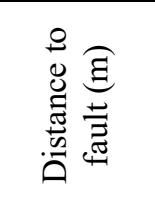 } & $0-1000$ & 115652656 & 1292344 & 0.096 & -0.006 & 0.994 & -0.006 \\
\hline & $1000-2000$ & 77380156 & 1429219 & 0.690 & 0.497 & 1.643 & 0.396 \\
\hline & $2000-3000$ & 74347500 & 1792188 & 1.024 & 0.763 & 2.145 & 0.540 \\
\hline & $3000-4000$ & 71559063 & 658750 & -0.119 & -0.200 & 0.819 & -0.183 \\
\hline & $>4000$ & 369320781 & 2787969 & -0.609 & -0.398 & 0.672 & -0.331 \\
\hline \multirow{5}{*}{ 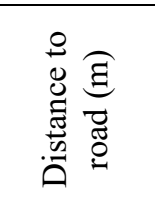 } & $0-100$ & 28052031 & 1428594 & 2.265 & 1.511 & 4.531 & 0.788 \\
\hline & $100-200$ & 22678594 & 478438 & 1.224 & 0.630 & 1.877 & 0.473 \\
\hline & $200-300$ & 20395938 & 252031 & 0.653 & 0.095 & 1.099 & 0.091 \\
\hline & $300-400$ & 37444531 & 364375 & 0.401 & -0.144 & 0.866 & -0.136 \\
\hline & $>400$ & 599689063 & 5437031 & -0.401 & -0.215 & 0.807 & -0.195 \\
\hline \multirow{5}{*}{ 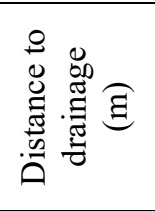 } & $0-100$ & 72580469 & 2091094 & 1.352 & 0.941 & 2.563 & 0.617 \\
\hline & $100-200$ & 68517344 & 1428438 & 0.919 & 0.618 & 1.855 & 0.466 \\
\hline & $200-300$ & 65953750 & 717188 & 0.158 & -0.033 & 0.967 & -0.033 \\
\hline & $300-400$ & 63086250 & 590781 & -0.006 & -0.182 & 0.833 & -0.168 \\
\hline & $>400$ & 438122344 & 3132969 & -0.732 & -0.452 & 0.636 & -0.366 \\
\hline \multirow{8}{*}{$\begin{array}{l}\text { } \\
\frac{0}{00} \\
\bar{\Xi} \\
\tilde{\Xi} \\
\frac{0}{0} \\
\frac{0}{\sim}\end{array}$} & $0-15$ & 50185156 & 291719 & -0.699 & -0.659 & 0.517 & -0.486 \\
\hline & $15-25$ & 91993750 & 737813 & -0.381 & -0.337 & 0.714 & -0.289 \\
\hline & $25-30$ & 135663125 & 1143594 & -0.346 & -0.288 & 0.750 & -0.252 \\
\hline & $30-35$ & 149727813 & 1442188 & -0.192 & -0.154 & 0.857 & -0.144 \\
\hline & $35-40$ & 129299531 & 1601094 & 0.124 & 0.097 & 1.102 & 0.093 \\
\hline & $40-45$ & 92902500 & 1512188 & 0.449 & 0.370 & 1.448 & 0.313 \\
\hline & $45-55$ & 45794688 & 914219 & 0.642 & 0.574 & 1.776 & 0.442 \\
\hline & $>55$ & 12693594 & 317656 & 0.840 & 0.800 & 2.227 & 0.557 \\
\hline \multirow{8}{*}{ 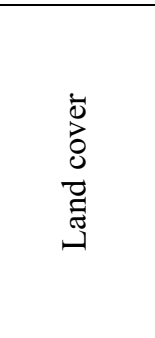 } & Type 1 & 3932656 & 33594 & -0.277 & -0.820 & 0.440 & -0.562 \\
\hline & Type 2 & 42225156 & 265469 & -0.586 & -0.274 & 0.760 & -0.242 \\
\hline & Type 3 & 90715938 & 1277656 & 0.228 & -2.079 & 0.125 & -0.876 \\
\hline & Type 4 & 3062344 & 15156 & -0.827 & -0.581 & 0.559 & -0.443 \\
\hline & Type 5 & 316212500 & 1530469 & -0.849 & 0.226 & 1.253 & 0.204 \\
\hline & Type 6 & 110146719 & 2986563 & 0.897 & 0.881 & 2.412 & 0.592 \\
\hline & Type 7 & 136849063 & 1844375 & 0.184 & -0.843 & 0.431 & -0.572 \\
\hline & Type 8 & 5115781 & 7188 & -2.089 & 0.182 & 1.199 & 0.168 \\
\hline \multirow{5}{*}{ 文 } & Type 1 & 171195313 & 2823906 & 0.445 & 0.384 & 1.468 & 0.322 \\
\hline & Type 2 & 193863281 & 3630938 & 0.703 & 0.511 & 1.666 & 0.404 \\
\hline & Type 3 & 199057031 & 1245469 & -0.860 & -0.586 & 0.557 & -0.446 \\
\hline & Type 4 & 102632656 & 220313 & -1.902 & -1.656 & 0.191 & -0.811 \\
\hline & Type 5 & 41511875 & 39844 & -2.634 & -2.460 & 0.085 & -0.915 \\
\hline
\end{tabular}

$I_{i}=\ln \left(\frac{\text { DensClass }}{\text { DenMap }}\right)=\ln \left(\frac{S_{i} / N_{i}}{S / N}\right)$

Where $I_{i}$ is the is the weight for each class of a causative factor, DensClass is landslide density in each class of a causative factor, DensMap is landslide density within the entire region, $S i$ is the causative factor $i$ landslide pixels, $N i$ is the causative factor $i$ total pixels, $S$ is the total landslide pixels of causative factor class, $N$ is the total pixels in the causative factor class.

The IVM weight results obtained by using equation 6 are shown in Table 3. The calculated weight values against each class of causative factors are then used to produce the landslide susceptibility map by using the following equation: 
$L S M_{I}=\sum_{i=1}^{M} X_{j i x} I_{i}$

Where $M$ is the number of classes of causative factors, $X j i$ is valued 0 if class $i$ is absent and 1 if class $i$ is present in factor $j$.

\subsubsection{FREQUENCY RATIO}

The frequency ratio (FR) is a quantitative landslide susceptibility method for spatial prediction of landslides based on the bivariate statistical approach. Various researchers have widely used this technique to develop a reliable landslide susceptibility assessment (Lee and Talib, 2005; Yalcin et al., 2011b; Chen et al., 2016). FR method evaluates the relationship between the past landslides and their causative factors. Each class of causative factors is analyzed against landslide pixels in the respective class to calculate the FR weight by using the following formula:

$F R=\frac{N p i x(S i) / N p i x(N i)}{\sum N p i x(S i) / \sum N p i x(N i)}$

Where Npix(Si) and Npix(Ni) represents the landslide pixels and total pixels of class $i$-th respectively, $\sum N p i x(S i)$ and $\sum N p i x(N i)$ represents the landslide pixels and total pixels of all causative factors, respectively.

The results of weights calculated with the FR model are presented in Table 3. The values obtained by the integration of statistical analysis are used to reclassify the thematic causative factor maps. Their summation is used to produce the landslide susceptibility map, as given in the following equation.

$L S M_{F R}=\sum F R$

\subsubsection{CERTAINTY FACTOR}

Shorthliffe and Buchanan (1975) introduced the certainty factor $(\mathrm{CF})$ approach, and later it was modified by Heckerman (1992) for its application in landslide susceptibility assessment and followed by several researchers (Binaghi et al., 1998; Pradhan et al., 2012; Devkota et al., 2013; Pourghasemi et al., 2013; Wang et al., 2019). In this approach, the CF is formulated for each causative factor by evaluating the landslide inventory and the combination of heterogeneous data (Sujatha et al., 2012; Devkota et al., 2013; Liu et al., 2014). The CF weights of causative factors are calculated statistically by evaluating the relationship between landslide influencing factors and the landslide inventory. CF value is measured by using the following probability function equation:

$C F=\left\{\begin{array}{l}\frac{P P_{a}-P P_{s}}{P P_{a} \cdot\left(1-P P_{s}\right)} \text { if } P P_{a} \geq P P_{S}, \\ \frac{P P_{a}-P P_{s}}{P P_{S} \cdot\left(1-P P_{a}\right)} \text { if } P P_{a}<P P_{S},\end{array}\right.$

Where PPa is the conditional probability of area in the subclass a of the causative factor, and PPS is the prior probability of total area of the causative factor.
The weights of each causative factor were calculated using equation 10 and corresponding causative factor $\mathrm{CF}$ values were combined with the causative factor layers to generate the landslide susceptibility map. A combination of two CF values, $\mathrm{X}$ and $\mathrm{Y}$ from two different layers of information is a CF value $Z$ obtained as follows (Binaghi et al., 1998; Pourghasemi et al., 2013):

$$
Z=\left\{\begin{array}{cr}
X+Y-X Y & X, Y \geq 0 \\
\frac{X+Y}{1-\min (|X|,|Y|)} & X, Y \text { Opposite sign } \\
X+Y+X Y & X, Y<0
\end{array}\right.
$$

As mentioned in the above equation, the pairwise combination of all causative factors layers was made to develop the susceptibility map. The natural break method was adopted in ArcGIS to divide the map into different zonation classes.

\subsection{VALIDATION OF THE LANDSLIDE SUSCEPTIBILITY MAPS}

The evaluation of any landslide susceptibility model is a challenging task performed to check the model's reliability and uncertainties in the results. The performance of any statistical-based landslide susceptibility assessment model depends on the conceptual and mathematical capability of the model, the ability to handle the sensitivity of input data, and the model's prediction accuracy (Beguería, 2006; Aditian et al, 2018; Chen et al., 2017; Saha et al., 2020). In practice, the predictive power of a landslide susceptibility model is evaluated by separating the landslide inventory into two datasets (i.e., model training and tests). In the present research, the landslide inventory is divided into training and test dataset by random selection of landslides with a ratio of $70 \%$ and $30 \%$, respectively. The training dataset was used to generate the susceptibility maps, and the test dataset was used to analyze the accuracy of the model.

The sensitivity analysis takes account of the two type of errors: false-positive (represents the misclassification of a unit as unstable; however, the unit has no landslide occurrence), and false-negative (represents the misclassification of a unit as stable; however, the unit has the presence of landslide occurrence). The sensitivity analysis of the present research work was performed by the receiver operating characteristic (ROC) curves of cutoff-independent accuracy statistics techniques (Yalcin, 2008; Corominas et al., 2014; Van Westen et al., 2008; Swets, 1988). The accuracy of landslide zonation models is assessed by the area under the curve (AUC) of the ROC curve. The larger area under the curve indicates the better performance of the model for predicting correctly on predefined events of landslide occurrence and non-occurrence. The AUC value close to 1.0 represents the excellent result of the test model, whereas a value close to 0.5 represents the poor prediction results of the test model, and below this value, the model is considered as a failure. 
The performance of models is evaluated by plotting true positive and false positive points to calculate the AUC on the base of the cumulative percentage of correctly and incorrectly classified discrimination threshold. The ROC curve is plotted by using equation 12 and 13 , the $\mathrm{x}$-axis represents the false-positive (1 - specificity), and the y-axis represents the true-positive (sensitivity).

$$
\begin{aligned}
& X=1-\text { specificity }=1-\left[\frac{T N}{T N+F P}\right] \\
& Y=\text { sensitivity }=\left[\frac{T N}{T P+F N}\right]
\end{aligned}
$$

\section{RESULTS AND DISCUSSION}

\subsection{MODELING RESULTS OF THE WEIGHT OF EVIDENCE METHOD}

The spatial relationship between landslide causative factors and landslide inventory was computed by the WOE model (Table 3) and graphically represented in Figure 5. The landslide susceptibility map produced by the WOE model is shown in Figure 6a. Based on the WOE weight, the Murree Formation (group 3) in the causative factor of lithology has a maximum value $(0.869)$, followed by the Panjal Volcanics (group 5) having a value of 0.679, and both classes are found to be more prone to landslide. For proximity to the fault, the positive weights for the classes of distance to fault range between 0 to $3000 \mathrm{~m}$ show the positive WOE weights, indicating the high susceptibility in these classes. The proximity to road shows the highest WOE value of 2.265 for the class $0-100 \mathrm{~m}$, and the values decreased as the distance to road increases. The lowest value $(-0.401)$ was observed for the class with the maximum distance to road $(>400 \mathrm{~m})$. For the distance to drainage causative factor, the class $0-100 \mathrm{~m}$ is highly susceptible to landslide in this causative factor with a WOE value of 1.352. In the case of slope angle, the highest value of 0.840 observed for the class having a slope angle $>55^{\circ}$, followed by the class $45^{\circ}-55^{\circ}$ with a value of 0.642 . The slopes with an angle of less than $35^{\circ}$ are less influential as the weight value becomes negative. In the case of causative factor land cover, the weight values are positive for the classes of bare ground (1.230), shrubland (0.296), and agricultural land with scattered houses (0.263). Other classes of causative factor land cover are not influencing as their weight values are negative. The class of meager vegetation in the causative factor NDVI has a high value of 0.703 , followed by the class no vegetation $(0.445)$.

\subsection{MODELING RESULTS OF THE INFORMATION VALUE METHOD}

The computed results of IVM by evaluating the landslide causative factors and landslide inventory are shown in Table 3. The landslide susceptibility map produced by IVM is shown in Figure 6b. For the causative factor of lithology, the Panjal Volcanics (0.955), Quaternary deposits (0.484), and Murree Formation (0.483) are the most susceptible lithologies for the occurrence of landslides. For the causative factor distance to fault, the highest IVM value of 0.763 was observed for the class 2000-3000 m, followed by the class $1000-2000 \mathrm{~m}$ with a value of 0.497 . The proximity to road causative factor shows the highest weight of 1.511 for class $0-100 \mathrm{~m}$ and a gradual decrease in class weight values observed as the distance to road increases. In the results of distance to drainage factor, the class $0-100 \mathrm{~m}$ is more susceptible to landslide showing the highest IVM weight of 0.914 . In the slope angle causative factor, the highest weight of 0.800 was observed for the class with the slope angle $>55^{\circ}$, and the gentler slopes are less susceptible to having relatively lower weights. The causative factor of land cover shows that the highest value of 0.226 was observed for the class shrubland, followed by the bare ground $(0.881)$. In the case of factor NDVI, the highest IVM value (0.511) was observed for the "meager vegetation" class, followed by the "no vegetation" class $(0.384)$.

\subsection{MODELING RESULT OF THE FREQUENCY RATIO METHOD}

The landslide susceptibility map developed by analyzing the relationship between landslide inventory and the causative factors using FR approach is shown in Figure 6c. The FR weights assessed for causative factors are shown in Table 3 and graphically presented in Figure 5.

Results of the lithology causative factor show that the FR value of Panjal Volcanics is 2.597, which is the highest weight in the causative factor of lithology, thus prone to landslides. In the case of factor distance to fault, the high FR weight of 2.145 was observed for the class 2000-3000 m, and the lowest value (0.672) was observed for class with the proximity of greater than $4000 \mathrm{~m}$. From the analysis of causative factor distance to road, the class $0-100 \mathrm{~m}$ has the highest FR value of 4.531 , followed by class 100-200 $\mathrm{m}$ (1.877). In the case of distance to drainage, the class $0-100 \mathrm{~m}$ has the highest FR weight of 2.563 . The causative factor slope angle results show that the class $>55^{\circ}$ has the highest FR value (2.227). For the causative factor of land cover, the maximum weight of 2.412 was observed for the class "bare ground". The FR value (1.666) of class "no vegetation" is the highest among other classes of the causative factor NDVI.

\subsection{MODELING RESULTS OF THE CERTAINTY FACTOR METHOD}

The results of the statistical analysis of landslide causative factors with the landslide inventory using the CF model is sown in Table 3. The landslide susceptibility map generated using these computed values is shown in Figure 6. The $\mathrm{CF}$ results for causative factor lithology show that Panjal Volcanics (0.622), Quaternary deposits (0.388), Murree Formation (0.388), and Panjal Metasediments (0.274) are prone to landslides. The proximity to the fault, road, and drainage were analyzed for evaluating the contribution of these causative factors and the class 

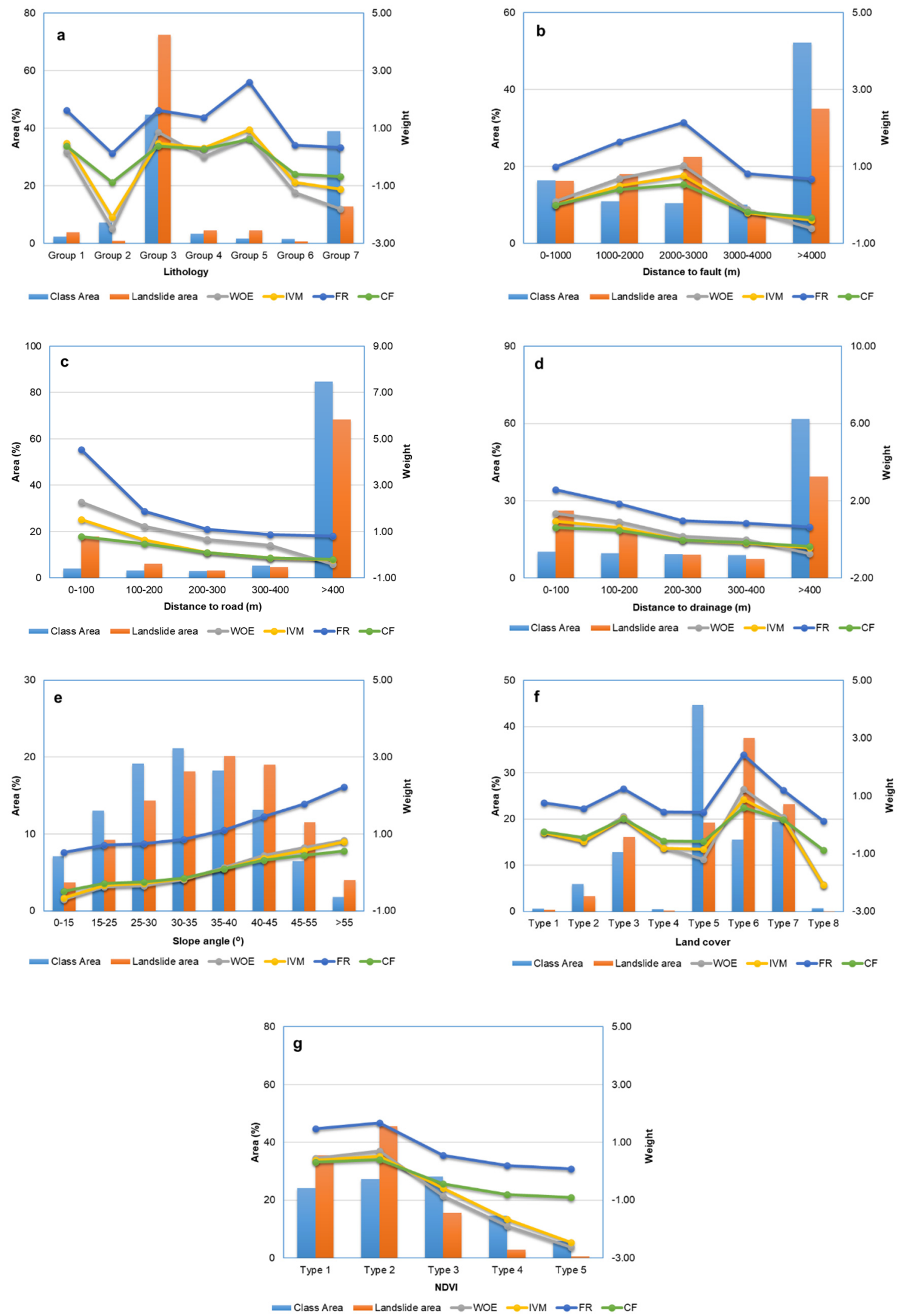

Fig. 5 Graphical representation of the class area and landslide area and models weights (a) lithology, (b) distance to fault, (c) distance to road, (d) distance to drainage, (e) slope angle, (f) land cover, and (g) NDVI. 

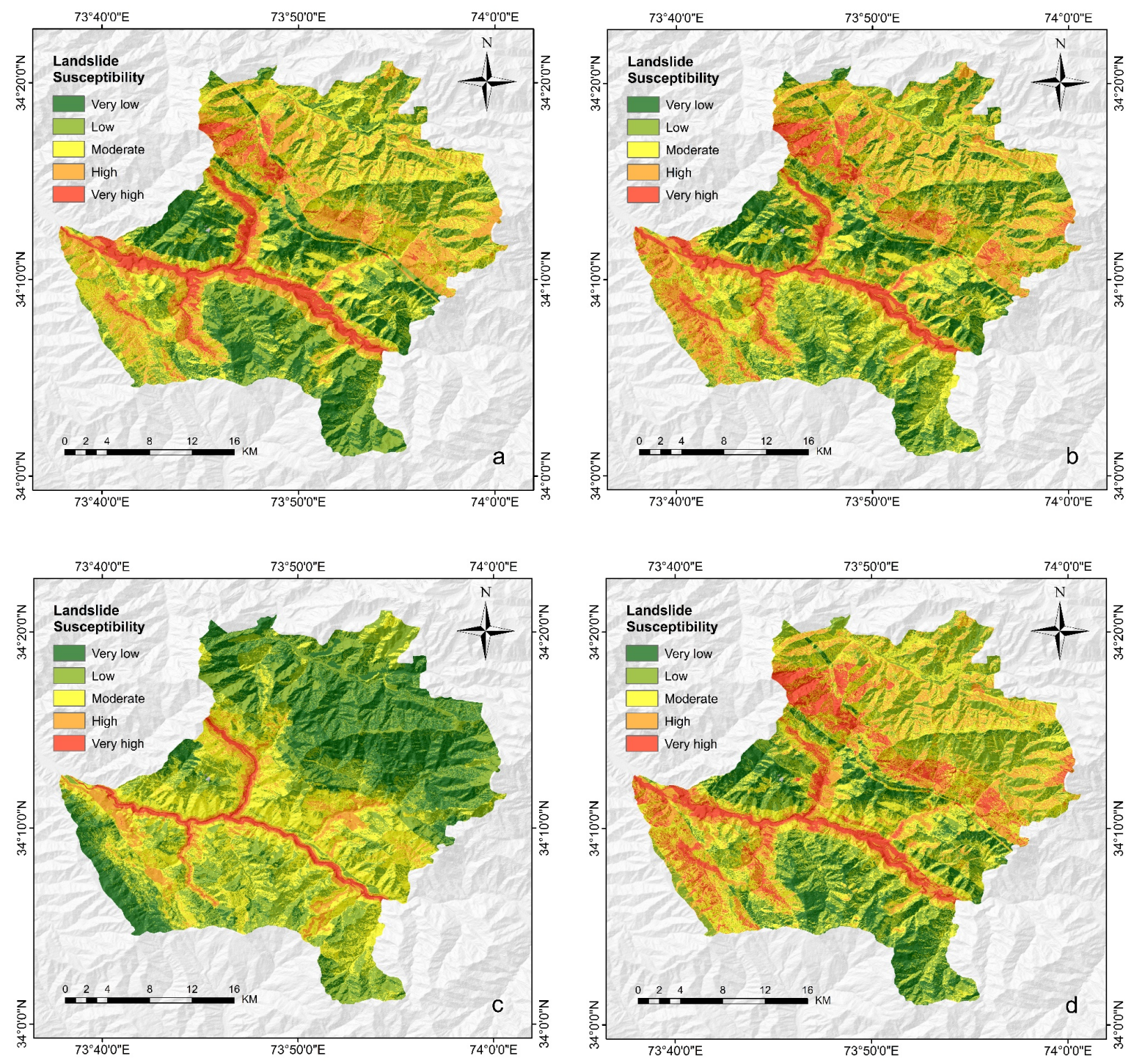

Fig. 6 Landslide susceptibility maps of the study area, (a) map generated by the WOE model, (b) map generated by the IVM model, (c) map generated by the FR model, (d) and map generated by the CF model.

2000-3000 $\mathrm{m}$ in causative factor distance to fault, the class $0-100 \mathrm{~m}$ in causative factor distance to road, and class $0-100 \mathrm{~m}$ in causative factor distance to drainage showed the highest CF values of $0.540,0.788$, and 0.617 respectively. In the case of slope angle, the class $>55^{\circ}$ showed the highest weight, thus this class of causative factor slope angle is more prone to landslide. For causative factor land cover, the class bare ground has the highest $C F$ value (0.592). The CF value (0.404) of class "meager vegetation" is the highest among other class of the causative factor NDVI.

\subsection{EVALUATION OF LANDSLIDE SUSCEPTIBILITY MAPS}

The landslide susceptibility map presents the spatial distribution of the prediction of landslide-prone areas in a systematic way. However, for each data-driven model, the difference in the theoretical basis leads to produce variations for predicting landslide susceptibility even in the same region. Therefore, it is valuable to compare the landslide susceptibility maps obtained with the different approaches for a clear overview of the area's correct distinctions. This comparison can be established by determining the percentage of actual landslide areas in different landslide susceptibility zones.

Four different data-driven approaches were used to produce the landslide susceptibility maps of the study area. For each model, the landslide contributing factors were constant and the weights of considered factors were statistically computed corresponding to the model procedure. The maps generated using the calculated values were then divided into different susceptibility zones. In the comparison of prediction 


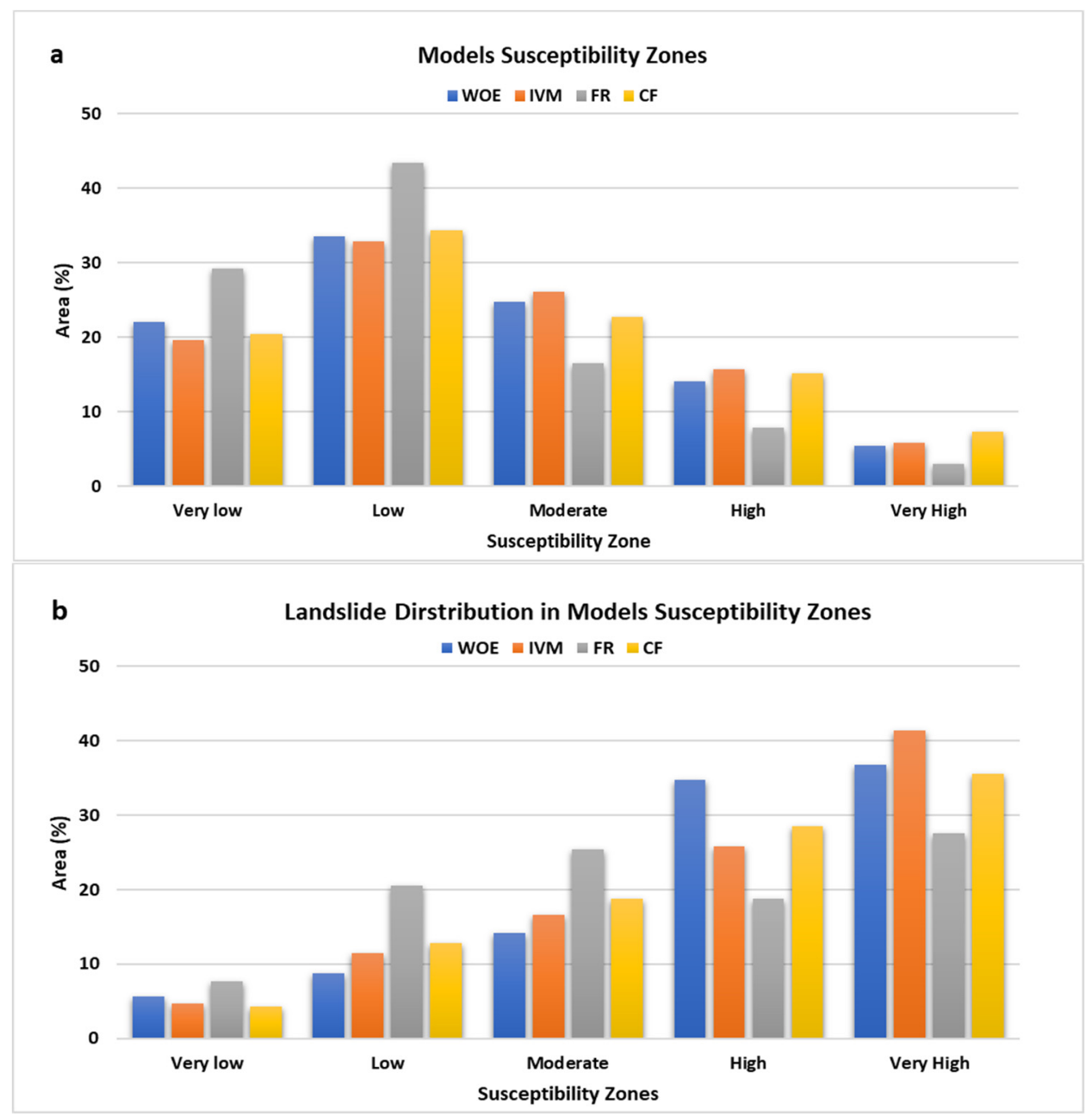

Fig. 7 (a) Comparison of the relative distribution of susceptibility zones of models, (b) Comparison of the relative distribution of landslides in susceptibility zones of models.

of these susceptibility zones, the FR model predicted less percentage of area in moderate to very high susceptible zones and a higher percentage of area in low to very low susceptible zones. The CF model predicted less percentage of area for a moderate and higher percentage of area for a very low susceptible zone. Other susceptibility zones of the models showed similarity in the results of the prediction area.

The reliability of the statistical based landslide susceptibility model is assessed on the accurate prediction of different susceptibility zones and by the comparison of past landslides in respective zones. The comparison of models predicted area of different susceptibility zones and the percentage of past landslide area in respective zones is shown in Figure 7.

The uncertainties are considered a common phenomenon in landslide susceptibility assessment, caused by the poor quality of input data or lack of knowledge. Sensitivity analysis is often performed to identify the parameters which are influencing the uncertainty in output results and quantifying those parameters which are exerting the greatest positive influence (Chung and Fabbri, 1999; Saha et al., 2020). The efficiency of statistical approaches depends on the model's conceptual capability and ability to deal with data (Van-Westen et al., 2003; Martha et al., 2013; Guri and Patel, 2015). The sensitivity analysis was performed to check the assessed models performance using receiver operating characteristic (ROC) curves. In this analysis, the accuracy of models is assessed by the area under the curve (AUC), as shown in Figure 8. The larger area under the curve indicates better performance of the model for predicting correctly on predefined events of landslide occurrence and nonoccurrence. The AUC value close to 1.0 represents the excellent result of the test model, whereas a value close to 0.5 represents the poor prediction results of the test model, and values below this is an indication of model failure. The AUC of both the training dataset (success rate) and the test dataset (prediction rate) were obtained. As shown in Table 4, the results of AUC demonstrate that all models fall in good classification. For success rate AUC results, the WOE model $(0.80)$ showed the highest AUC value, followed 

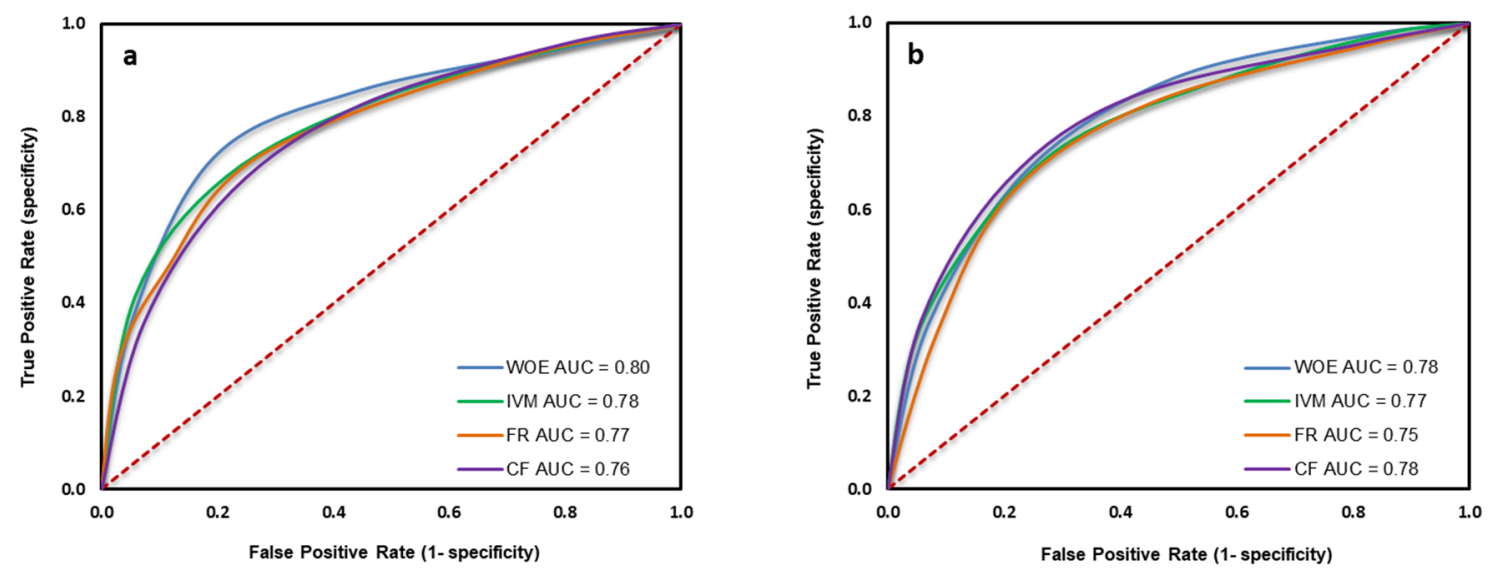

Fig. 8 AUC curves of models (a) success rate curves (b) prediction rate curves.

Table 4 AUC values of the models success rate and prediction rate.

\begin{tabular}{lcc}
\hline Models & Success rate & Prediction rate \\
\hline WOE & 0.80 & 0.78 \\
IVM & 0.78 & 0.77 \\
FR & 0.77 & 0.75 \\
CF & 0.76 & 0.78 \\
\hline
\end{tabular}

by the IVM model (0.78), the FR model (0.77), and the $\mathrm{CF}$ model $(0.76)$. The success rate method is suitable for assessing the performance of the models. However, as it utilizes the landslide training dataset, it is not suitable for evaluating the models prediction capability (Devkota et al., 2013). Thus, the prediction rate curve was used for the validation of the models. The AUC results of the prediction rate showed that both WOE and CF model has the highest $\mathrm{AUC}$ value (0.78), followed by the IVM model (0.77), and the FR model $(0.75)$. The success rate and prediction rate curve show that all the models applied for the assessment of landslide susceptibility of the study area have reasonably good accuracy of results.

\section{CONCLUSIONS}

Landslide susceptibility assessment provides essential information for landslide risk assessment and management. To investigate the landslide hazards, direct geomorphological access in mountainous areas is virtually impossible. Remote sensing techniques offer effective solutions for identifying and monitoring the landslides and associated causative factors. With the use of geospatial tools like RS and GIS, and comparing various quantitative approaches for landslide susceptibility assessment, this study is expected to produce a reliable susceptibility assessment and contribute to the advancement of effective strategies for the development of landslide susceptibility maps.

The present research aimed to evaluate various landslide contributing factors for integrated approaches of landslide susceptibility mapping and to compare the efficacy of these data-driven approaches using WOE, IVM, FR, and CF models. The landslide susceptibility maps are presented by categorizing the study area into different landslide susceptibility zones. The assessed models were based on a landslide inventory and the integration of landslide contributing factors.

The computed results of landslide causative factors concluded that these selective variables, different spatial biases, influence the slope instability. It can be revealed that landslide distribution is largely influenced by a combination of geological and geomorphological conditions, such as the presence of various prone lithologies, proximity to a fault line, road and stream, slope angle, land cover, and NDVI. More importantly, the present research work attempts to offer a comparative study of the assessment of used models for the landslide susceptibility zonation. The evaluation of the results showed a reasonably good relationship between the spatial location of past landslides and the developed susceptibility map. These applied approaches are simple and cost-effective and can be implemented in areas with similar geological and geomorphological conditions. The validation of results demonstrated that the weight of the evidence model has the highest accuracy results for the success rate $(0.80)$, followed by the information value method $(0.78)$, frequency ratio $(0.77)$, and certainty factor $(0.76)$. Similarly, for the prediction rate, the weight of evidence and certainty factor has the highest accuracy results $(0.78)$, followed by the information value method $(0.77)$, and certainty factor (0.75). The overall performance of all models falls in good classification. 
In the present study, the areas of commercial dealings, villages, and road networks required more detailed investigations and mitigation measurements to prevent landslides. If utilizing landslide susceptibility as a preliminary tool to prevent future growth without engineering measurements in the areas classified as high to very high susceptible zones, loss of human life and property can be avoided. The finding of this study is of utmost relevance for government officials and urban planners to manage the increasing pressure of population and the infrastructure development at the regional level.

\section{REFERENCES}

Abella, E.A.C. and Van-Westen, C.J.: 2008, Qualitative landslide susceptibility assessment by multicriteria analysis. A case study from San Antonio del Sur, Guantanamo, Cuba. Geomorphology, 94, 453-466. DOI: 10.1016/j.geomorph.2006.10.038

Aditian, A., Kubota, T. and Shinohara, Y.: 2018, Comparison of GIS-based landslide susceptibility models using frequency ratio, logistic regression, and artificial neural network in a tertiary region of Ambon, Indonesia. Geomorphology, 318, 101-111. DOI: 10.1016/j.geomorph.2018.06.006

Anbalagan, R.: 1992, Landslide hazard evaluation and zonation mapping in mountainous terrain. Eng. Geol., 32, 4, 269-277. DOI: 10.1016/0013-7952(92)90053-2

Basharat, M., Rohn, J., Ehret, D. and Baig, M.S.: 2012, Lithological and structural control of Hattian Bala rock avalanche triggered by the Kashmir earthquake 2005, Sub-Himalayas, Northern Pakistan. J. Earth Sci., 23, 2, 213-224. DOI: $10.1007 / \mathrm{s} 12583-012-0248-3$

Beguería, S.: 2006, Validation and evaluation of predictive models in hazard assessment and risk management. Nat. Hazards, 37, 3, 315-29. DOI: 10.1007/s11069-005-5182-6

Binaghi, E., Luzi, L., Madella, P., Pergalani, F. and Rampini, A.: 1998, Slope instability zonation: a comparison between certainty factor and Fuzzy Dempster-Shafer approaches. Nat. Hazards, 17, 77-97. DOI: $10.1023 / \mathrm{A}: 1008001724538$

Bonham-Carter, G.F.: 2014, Geographic information systems for geoscientists modelling with GIS., Elsevier. DOI: 10.1016/C2013-0-03864-9

Bonham-Carter, G.F.: 1989, Weights of evidence modeling: a new approach to mapping mineral potential. Stat. Appl. Earth Sci., 171-183.

Bossart, P. and Ottiger, R.: 1989, Rocks of the Murree Formation in northern Pakistan: indicators of a descending foreland basin of late Paleocene to middle Eocene age. Eclogae. Geol. Helv., 82, 1, 133-165.

Carrara, A., Cardinali, M., Guzzetti, F. and Reichenbach, P.: 1995, GIS technology in mapping landslide hazard. In: Geographical information systems in assessing natural hazards. Springer, 135-175. DOI: $10.1007 / 978-94-015-8404-3-8$

Chang, Z., Du, Z., Zhang, F., Huang, F., Chen, J. and Li, W.: 2020, Landslide susceptibility prediction based on remote sensing images and gis: Comparisons of supervised and unsupervised machine learning models. Remote Sens., 12, 3-502.

DOI: $10.3390 /$ rs 12030502
Chen, T., Niu, R. and Jia, X.: 2016, A comparison of information value and logistic regression models in landslide susceptibility mapping by using GIS. Environ. Earth Sci., 75, 10-867. DOI: $10.1007 / \mathrm{s} 12665-016-5317-y$

Chen, W., Chai, H., Sun, X., Wang, Q., Ding, X. and Hong, H.: 2016, A GIS-based comparative study of frequency ratio, statistical index and weights-ofevidence models in landslide susceptibility mapping. Arab. J. Geosci. 9, 3-204. DOI: $10.1007 / \mathrm{s} 12517-015-2150-7$

Chen, W., Ding, X., Zhao, R. and Shi, S.: 2016, Application of frequency ratio and weights of evidence models in landslide susceptibility mapping for the Shangzhou District of Shangluo City, China. Environ. Earth Sci., 75, 1-64. DOI: 10.1007/s12665-015-4829-1

Chen, W., Xie, X., Wang, J., Pradhan, B., Hong, H., Bui, D.T., Duana, Z. and Maa, J.: 2017, A comparative study of logistic model tree, random forest, and classification and regression tree models for spatial prediction of landslide susceptibility. Catena, 151, 147-160. DOI: 10.1016/j.catena.2016.11.032

Chung, C.J.F. and Fabbri, A.G.: 1999, Probabilistic prediction models for landslide hazard mapping. Photogramm. Eng. Remote Sens., 65, 12, 1389-1399.

Corominas, J., Van-Westen, C.J., Frattini, Cascini, L., Malet, L.P. and Fotopoulou, S.: 2014, Recommendations for the quantitative analysis of landslide risk. Bull. Eng. Geol. Environ., 73, 2, 209263. DOI: $10.1007 / \mathrm{s} 10064-013-0538-8$

Devkota, K.C., Regmi, A.D., Pourghasemi, H.R., Yoshida, K., Pradhan, B. and Ryu, I.C.: 2013, Landslide susceptibility mapping using certainty factor, index of entropy and logistic regression models in GIS and their comparison at Mugling-Narayanghat road section in Nepal Himalaya. Nat. Hazards, 65, 1, 135-165. DOI: $10.1007 / \mathrm{s} 11069-012-0347-6$

Dikshit, A., Sarkar, R., Pradhan, B., Acharya, S. and Alamri, A.M.: 2020, Spatial landslide risk assessment at Phuentsholing, Bhutan. Geosci., 10, 4-131. DOI: $10.3390 /$ geosciences10040131

Du, G., Zhang, Y., Iqbal, J., Yang, Z. and Yao, X.: 2017, Landslide susceptibility mapping using an integrated model of information value method and logistic regression in the Bailongjiang watershed, Gansu Province, China. J. Mt. Sci., 14, 2, 249-268. DOI: $10.1007 / \mathrm{s} 11629-016-4126-9$

Duman, T.Y., Can, T., Emre, Ö., Keçer, M., Doğan, A. and Ates, S.: 2005, Landslide inventory of northwestern Anatolia, Turkey. Eng. Geol., 77, 1, 99-114. DOI: $10.1016 /$ j.enggeo.2004.08.005

Dunning, S.A., Mitchell, W.A., Rosser, N.J. and Petley, D.N.: 2007, The Hattian Bala rock avalanche and associated landslides triggered by the Kashmir Earthquake of 8 October 2005. Eng. Geol., 93, 3, 130 144. DOI: $10.1016 /$ j.enggeo.2007.07.003

Ghosh, S., Van-Westen, C.J., Carranza, E.J.M., Jetten, V.G., Cardinali, M. and Rossi, M.: 2012, Generating eventbased landslide maps in a data-scarce Himalayan environment for estimating temporal and magnitude probabilities. Eng. Geol., 128, 49-62. DOI: 10.1016/j.enggeo.2011.03.016

Guo, C., Montgomery, D.R., Zhang, Y., Wang, K. and Yang, Z.: 2015, Quantitative assessment of landslide susceptibility along the Xianshuihe fault zone, Tibetan Plateau, China. Geomorphology, 248, 93-110. DOI: 10.1016/j.geomorph.2015.07.012 
Gupta, R.P. and Joshi, B.C.: 1990, Landslide hazard zoning using the GIS approach - a case study from the Ramganga catchment, Himalayas. Eng. Geol., 28, 2, 119-131. DOI: 10.1016/0013-7952(90)90037-2

Guri, P.K. and Patel, R.C.: 2015, Spatial prediction of landslide susceptibility in parts of Garhwal Himalaya, India, using the weight of evidence modelling. Environ. Monit. Assess., 187, 6, 324. DOI: $10.1007 / \mathrm{s} 10661-015-4535-1$

Guzzetti, F.: 2002, Landslide hazard assessment and risk evaluation: Limits and prospectives. Proc. 4th Plinius Conference on Mediterranean Storms. Universitat de Illes Baleares, Mallorca, Spain.

Guzzetti, F., Mondini, A.C., Cardinali, M., Fiorucci, F., Santangelo, M. and Chang, K.: 2012, Landslide inventory maps: New tools for an old problem. EarthSci. Rev., 112, 1, 42-66.

DOI: $10.1016 /$ j.earscirev.2012.02.001

Harp, E.L. and Crone, A.J.: 2006, Landslides triggered by the October 8, 2005, Pakistan earthquake and associated landslide-dammed reservoirs. U.S. Geological Survey Open-file Report 2006-1052, 13 pp.

Heckerman, D.: 1992, The certainty-factor model. Encycl. Artif. Intell. 131-138.

Hicks, M.J. and Burton, M.L.: 2010, Preliminary damage estimates for Pakistani flood events, 2010. Cent. Bus. Econ. Res., Ball State Univ., 5-8.

Iqbal1, J., Peng, C., Hussain, M.L., Pourghasemi, H.R., DeQiang, C., Shah, S.U. and Pradhan, B.: 2021, Landslide susceptibility assessment along the dubairdudishal section of the Karakoram higway, northwestern Himalayas, Pakistan. Acta Geodyn. Geomater., 18, 2, 137-155. DOI: 10.13168/AGG.2021.0010

Kanungo, D.P., Sarkar, S. and Sharma, S.: 2011, Combining neural network with fuzzy, certainty factor and likelihood ratio concepts for spatial prediction of landslides. Nat. Hazards, 59, 3, 1491. DOI: $10.1007 / \mathrm{s} 11069-011-9847-\mathrm{z}$

Lee, S. and Talib, J.A.: 2005, Probabilistic landslide susceptibility and factor effect analysis. Environ. Geol., 47, 7, 982-990. DOI: $10.1007 / \mathrm{s} 00254-005-1228-\mathrm{z}$

Liu, M., Chen, X. and Yang, S.: 2014, Collapse landslide and mudslides hazard zonation. In: Landslide science for a safer geoenvironment. Springer, 457-462. DOI: 10.1007/978-3-319-05050-8-71

Mahmood, I., Qureshi, S.N., Tariq, S., Atique, L. and Iqbal, M. F.: 2015, Analysis of landslides triggered by October 2005, Kashmir Earthquake. PLoS. Curr., 7.

DOI: 10.1371/currents.dis.0bc3ebc5b8adf5c7fe9fd3d702d44a99

Martha, T.R., Van-Westen, C.J., Kerle, N., Jetten, V. and Kumar, K.V.: 2013, Landslide hazard and risk assessment using semi-automatically created landslide inventories. Geomorphology, 184, 139-150. DOI: 10.1016/j.geomorph.2012.12.001

Meena, S.R., Ghorbanzadeh, O. and Blaschke, T.: 2019, A comparative study of statistics-based landslide susceptibility models: A case study of the region affected by the Gorkha earthquake in Nepal. ISPRS. Int. J. Geo-Inf., 8, 2, 94. DOI: 10.3390/ijgi8020094

Nath, S.K.: 2004, Seismic hazard mapping and microzonation in the Sikkim Himalaya through GIS integration of site effects and strong ground motion attributes. Nat. Hazards, 31, 2, 319-342.

DOI: 10.1023/B:NHAZ.0000023355.18619.0c
Nohani, E., Moharrami, M., Sharafi, S., Khosravi, K., Pradhan, B. and Pham, B.T.: 2019, Landslide susceptibility mapping using different GIS-based bivariate models. Water, 11, 7, 1-22. DOI: $10.3390 /$ w1 1071402

Owen, L.A, Kamp, U., Khattak, G.A., Harp, E.L., Keefer, D.K. and Bauer, M.A.: 2008, Landslides triggered by the 8 October 2005 Kashmir earthquake. Geomorphology, 94, 2, 1-9. DOI: 10.1016/j.geomorph.2007.04.007

Pasang, S. and Kubíček, P.: 2020, Landslide susceptibility mapping using statistical methods along the Asian highway, Bhutan. Geosci., 10, 430. DOI: $10.3390 /$ geosciences10110430

Pascaline, W. and Rowena, H.: 2018, Economic losses, poverty \& disasters: $1998-2017$. United Nations Off Disaster Risk Reduction. DOI: $10.1002 / 9781119359203 . c h 3$

Pradhan, A.M.S., Dawadi, A. and Kim, Y.T.: 2012, Use of different bivariate statistical landslide susceptibility methods: A case study of Khulekhani watershed, Nepal. J. Nepal. Geol. Soc, 44, 1-12. DOI: $10.3126 /$ jngs.v44i0.24483

Pourghasemi, H.R., Pradhan, B., Gokceoglu, C., Mohammadi, M. and Moradi, H.R.: 2013, Application of weights-of-evidence and certainty factor models and their comparison in landslide susceptibility mapping at Haraz watershed, Iran. Arab. J. Geosci., 6 , 2351-2365. DOI 10.1007/s12517-012-0532-7

Raja, N.B., Çiçek, I., Türkoğlu, N., Aydin, O. and Kawasaki, A.: 2017, Landslide susceptibility mapping of the Sera River Basin using logistic regression model. Nat. Hazards, 85, 3, 1323-1346.

DOI: $10.1007 / \mathrm{s} 11069-016-2591-7$

Regmi, N.R., Giardino, J.R. and Vitek, J.D.: 2010, Modeling susceptibility to landslides using the weight of evidence approach: Western Colorado, USA. Geomorphology, 115, 2, 172-187. DOI: 10.1016/j.geomorph.2009.10.002

Reichenbach, P., Galli, M., Cardinali, M., Guzzetti, F. and Ardizzone, F.: 2005, Geomorphologic mapping to assess landslide risk: concepts, methods and applications in the Umbria Region of central Italy. In: Glade, T. et al. (eds.), Landslide Risk Assessment. John Wiley, 429-468. DOI: 10.1002/9780470012659

Saha, S., Saha, A., Hembram, T.K., Pradhan, B. and Alamri, A.M.: 2020, Evaluating the performance of individual and novel ensemble of machine learning and statistical models for landslide susceptibility assessment at Rudraprayag District of Garhwal Himalaya. Appl. Sci., 10, 11, 3772. DOI: 10.3390/app10113772

Sarkar, S., Kanungo, D.P., Patra, A.K. and Kumar, P.: 2012, GIS based landslide susceptibility mapping-A case study in Indian Himalaya. Proc. Interpraevent Int. Symp. on Disaster Mitigation of Debris Flows, Slope Failures and Landslides, Niigata, Japan, 617-624.

Sarkar, S., Roy, A.K. and Martha, T.R.: 2013, Landslide susceptibility assessment using information value method in parts of the Darjeeling Himalayas. J. Geol. Soc. India, 82, 4, 351-362. DOI: $10.1007 / \mathrm{s} 12594-013-0162-\mathrm{z}$

Schneider, J.F.: 2009, Seismically reactivated Hattian slide in Kashmir, Northern Pakistan. J. Seismol., 13, 3, 387398. DOI: 10.1007/s10950-008-9103-5

Shafique, M., van-der-Meijde, M. and Khan, M.A.: 2016, A review of the 2005 Kashmir earthquake-induced 
landslides; from a remote sensing prospective. J. Asian Earth Sci., 118, 68-80.

DOI: $10.1016 /$ j.jseaes.2016.01.002

Shortliffe, E.H. and Buchanan, B.G.: 1975, A model of inexact reasoning in medicine. Math. Biosci., 23, 3-4, 351-379. DOI: 10.1016/0025-5564(75)90047-4

Shu, H., Hürlimann, M., Molowny-Horas, R., González, M., Pinyol, J. and Abancó, C.: 2019, Relation between land cover and landslide susceptibility in Val d'Aran, Pyrenees (Spain): Historical aspects, present situation and forward prediction. Sci. Total Environ., 693, 133557. DOI: 10.1016/j.scitotenv.2019.07.363

Sujatha, E.R., Rajamanickam, G.V. and Kumaravel, P.: 2012, Landslide susceptibility analysis using probabilistic certainty factor approach: A case study on Tevankarai stream watershed, India. J. Earth Syst. Sci., 121, 5, 1337-1350.

DOI: $10.1007 / \mathrm{s} 12040-012-0230-6$

Swets, J.A.: 1988, Measuring the accuracy of diagnostic systems. Science, 240, 4857, 1285-93. DOI: $10.1126 /$ science. 3287615

Tibaldi, A., Ferrari, L. and Pasquarè, G.: 1995, Landslides triggered by earthquakes and their relations with faults and mountain slope geometry: an example from Ecuador. Geomorphology, 11, 3, 215-226. DOI: $10.1016 / 0169-555 X(94) 00060-5$

Van-Westen, C.J.: 2002, Use of weights of evidence modeling for landslide susceptibility mapping. International Institute for Geoinformation Science and Earth Observation, Enschede. Netherlands.

Van-Westen, C.J.: 1993, Application of geographic information systems to landslide hazard zonation. Ph.D Thesis.

Van-Westen, C.J., Rengers, N. and Soeters, R.: 2003, Use of geomorphological information in indirect landslide susceptibility assessment. Nat. Hazards, 30, 3, 399419. DOI: 10.1023/B:NHAZ.0000007097.42735.9e

Van-Westen, C.J., Castellanos, E. and Kuriakose, S.L.: 2008, Spatial data for landslide, hazard and vulnerability assessment: An overview. Eng. Geol., 102, 3, 112-31. DOI: 10.1016/j.enggeo.2008.03.010

Wang, J., Yin, K. and Xiao, L.: 2014, Landslide susceptibility assessment based on GIS and weighted information valuea case study of Wanzhou district, three gorges reservoir. Chin. J. Rock Mech. Eng., 33, 4, 797-808.
Wang, Q., Guo, Y., Li, W., He, J. and Wu, Z.: 2019, Predictive modeling of landslide hazards in Wen County, northwestern China based on information value, weights-of-evidence, and certainty factor. Geomat. Nat. Haz. Risk, 10, 1, 820-835. DOI: $10.1080 / 19475705.2018 .1549111$

Wittich, K.P. and Hansing, O.: 1995, Area-averaged vegetative cover fraction estimated from satellite data. Int. J. Biometeorol., 38, 4, 209-215. DOI: $10.1007 / \mathrm{BF} 01245391$

Xu, C., Xu, X., Lee, Y.H., Tan, X., Yu, G. and Dai, F.: 2012, The 2010 Yushu earthquake triggered landslide hazard mapping using GIS and weight of evidence modeling. Environ. Earth Sci., 66, 6, 1603-1616. DOI: $10.1007 / \mathrm{s} 12665-012-1624-0$

Yalcin, A.: 2008, GIS-based landslide susceptibility mapping using analytical hierarchy process and bivariate statistics in Ardesen (Turkey): comparisons of results and confirmations. Catena, 72, 1, 1-12. DOI: 10.1016/j.catena.2007.01.003

Yalcin, A., Reis, S., Aydinoglu, A.C. and Yomralioglu, T.: 2011, A GIS-based comparative study of frequency ratio, analytical hierarchy process, bivariate statistics and logistics regression methods for landslide susceptibility mapping in Trabzon, NE Turkey. Catena, 85, 3, 274-287.

DOI: $10.1016 /$ j.catena.2011.01.014

Yin, K.L. and Yan, T.Z.: 1988, Statistical prediction models for instability of metamorphosed rocks. Proc. $5^{\text {th }}$ International Symposium on Landslides, Lausanne, Switzerland 2, 1269-1272.

Zhao, X. and Chen, W.: 2020, GIS-based evaluation of landslide susceptibility models using certainty factors and functional trees-based ensemble techniques. Appl. Sci., 10, 1, 16. DOI: 10.3390/app10010016 